TAPROBANICA, ISSN 1800-427X. April, 2012. Vol. 04, No. 01: pp. 54-56.

(C) Taprobanica Private Limited, Jl. Kuricang 18 Gd.9 No.47, Ciputat 15412, Tangerang, Indonesia.

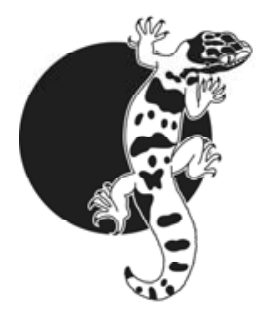

\section{Three tick species parasitizing a rock python in Sri Lanka}

Parasitism is a relationship where one of the parties (the parasite) either harms its host or lives at the expense of it (Roberts \& Javovy, 2000). Host parasite interactions are important driving forces in population dynamics and even extinction (Pedersen et al., 2007). These interactions are also indicators of ecosystem health (Marcogliese, 2005) and they are important in stabilizing food webs (Lafferty et al., 2008). A parasite may cause mechanical injury, stimulate a damaging inflammatory or immune response, or simply rob the host of nutrition (Poulin \& Brodeur, 1994). However in the wild most parasites must live in harmony with their hosts. If the parasites kill the host, they themselves would ultimately die without shelter and nutrition (Roger \& Kilingenberg, 1993). Reptiles become hosts to a number of parasitic organisms ranging from protozoans to arthropods (Fredric, 1991; Thomas \& Douglas, 1996). Among these, ticks (hard and soft) are the most common arthropod group that parasitizes reptiles (Roger \& Kilingenberg, 1993).

There are at least seven genera of ticks known to use reptile hosts: Amblyomma, Aponomma, Argas, Hyalomma, Haemaphysalia, Ixodes and Ornithodoras (Arthur, 1962). All Argas and Ornithodoros are hard ticks. Here, we report a new observation of three tick species found on the skin of the rock python in the wild. We observed an adult female rock python (Python molurus) (SVL, $168 \mathrm{~cm}$ ) was located under a wood apple tree, Feronia limonia (Family: Rutaceae) at the Wildlife training center, Randenigala, Sri Lanka, on October 30 2010. The female had recently ingested a large prey (approximately the size of $50 \mathrm{~cm}$ ) causing the skin of the python to expand allowing us to observe a heavy tick infection. The expanding skin exposed spaces between scales providing an area for a large number of ticks to reside. It was well visible that there were 6 morphologically distinct ticks were initially identified. Some of the ticks were about 10 $\mathrm{mm}$ in length due to their ingestion of blood. Others were clinging on to the python's skin in clusters just beneath the blood fed ticks. After thorough observation, all the ticks were removed carefully making sure that no damage was caused to the host or the parasites. A total of 165 ticks were collected and identified to the species level. We found that the ticks included both male and female ectoparasitic ticks (Ixoidia) and belonged to one of three species (Fig. 1); Aponomma gervaisi, Aponomma varanense and Ambyolomma clypeolatum. The most abundant species was Aponomma varanense $(\mathrm{n}=108)$ while Ambyolomma clypeolatum $(\mathrm{n}=8)$ was the least abundant.

Aponomma gervaisi was first reported from Sri Lanka by Neumann (1918) and later has been reportedly found on various host species in captivity (Python molurus: Fernando \& Randeniya, 2009; Seneviratne, 1965; Warburton, 1925; Varanus bengalensis: Sharif, 1928; Daboia russelii: Seneviratne, 1965; Naja naja: Fernando \& Randeniya, 2009). This is the first record of $A$. gervaisi found on a wild rock python. Sharif (1928) and Seneviratne (1965) reported Aponomma varanense ticks collected off on the land monitor (Varanus bengalensis). Fernando \& Randeniya (2009) reported Aponomma varanense collected off rock pythons and cobra in captivity. This is the first record of Aponomma varanense found on wild rock python. Warburton (1925), Robinson (1926), Seneviratne (1965) and Fernando \& Randeniya (2009) recorded Ambyolomma clypeolatum was collected off a star tortoise (Geochelone elegans) in captivity and this is a new host record of Ambyolomma clypeolatum on rock python from Sri Lanka.

This observation shows multiple tick infection in wild rock python in Sri Lanka. Proper scientific studies have not been done to show that parasitic infections lead to the decline of reptile population in Sri Lanka. Therefore this observation suggests a need for further studies on reptile population decline in Sri Lanka. 

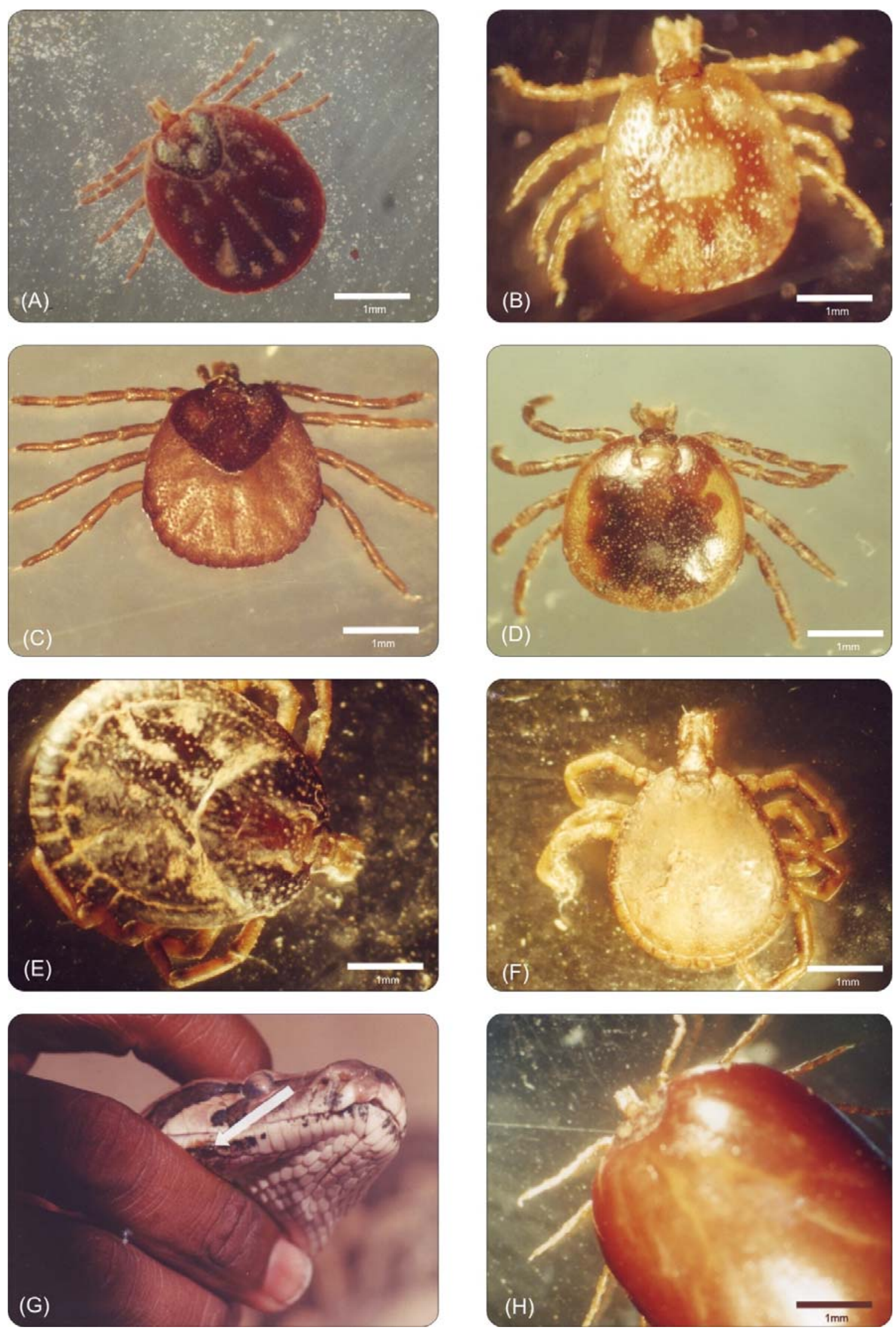

Figure 1: Different tick species found in the Rock Python (Python molurus) from Randenigala, Sri Lanka, dorsal view of (A) Aponomma gervaisi female (x14); (B) Aponomma gervaisi male (x14); (C) Aponomma varanense female (x14); (D) Aponomma varanense male (x14); (E) Ambyolomma clypeolatum female (x10); (F) Ambyolomma clypeolatum male (x10); (G) Aponomma gervaisi attachment on the skin (x0.2); (H) Aponomma gervaisi blood fed female (x10). 


\section{Acknowledgements}

We are grateful to Prof. Nixon Wilson, University of Northern Iowa, USA for the identification of tick species and his valuable comments. Finally we would like to thank Laura Johnson (Dalhousie University, Canada) and Jan Gogarten (McGill University, Canada) for reviewing the manuscript.

\section{Literature cited}

Arthur, D.R., 1962. Ticks and disease. International series of monographs on pure and applied biology. New York, Pergamum press.

Fernando, T. S. P. \& P. V. Randeniya, 2009. Ecto Parasites and intestinal parasites of some selected reptile species in National Zoological Gardens, Sri Lanka. Journal of Zoo and Wildlife diseases, 40 (2): 272-275.

Fredric, L. F. 1991. Applied clinical nonhemic Parasitology of reptiles, Malabar, Florida.

Lafferty, K. D., S. Allesina, M. Arim, C. J. Briggs, G. De Leo, A. P. Dobson, J. A. Dunne, P. T. J. Johnson, A. M. Kuris, D. J. Marcogliese, N. D. Martinez, J. Memmott, P. A. Marquet, J. P. McLaughlin, E. A. Mordecai, M. Pascual, R. Poulin, D. W. Thieltges, 2008. Parasites in food webs: the ultimate missing links. Ecology Letters, 11:533-546

Marcogliese, D. J. 2005. Parasites of the superorganism: are they indicators of ecosystem health?. International Journal of Parasitology, 35: 705-716.

Neumann, L. G., 1918. Notes sur les ixodidés III, Archives de Parasitologie, 9: 225-241.

Pedersen A. B., K. E. Jones, C. Nunn and S. Altizer. 2007. Infectious diseases and extinction risk in wild mammals. Conservation Biology, 21: 1269-1279.

Poulin, R. and J. Brodeur, 1994. Parasitic manipulation of host behavior: should host always lost?. Oikos, 70 (3) 479-484.

Roberts, L. S. and J. Javovy, 2000. Foundation of Parasitology. McGrew Hill Publications, USA.

Robinson, L. E., 1926. The genus Amblyomma in ticks: A monograph of the Ixodoidea. Cambridge University press: 302.

Roger, J. and D. V. M. Kilingenberg, 1993. Understanding reptile parasites. Herpetocultural library: 44-45.
Senevirantna, P., 1965. The ticks (Ixodoidea) of Ceylon. Ceylon veterinary Journal, 13(2): 30-41.

Sharif, M., 1928. A revision of the Indian Ixodidae, with special reference to the collection in the Indian museum. Research Indian museum, 30: 217-344.

Thomas, J. L., R. M. Douglas, 1996. Reptile Medicine and Surgery. In: Parasitology (Section II, chapter 16): 185-203.

Warburton, C., 1925. Report of the Ixodidae of the Colombo museum. Spolia zeylanica, 13: 255-256.

Submitted: 16 December 2011, Accepted: 30 April 2012 Sectional Editor: Colin A. Chapman

\section{T. S. P. Fernando ${ }^{1}$ and H. K. A. V. A. Kulasena} Fernando $^{2}$

${ }^{1}$ Dept. of Zoology, Faculty of Natural Sciences, The Open University of Sri Lanka, Nawala, Sri Lanka.

E-mail: saminda@ou.ac.lk

${ }^{2}$ Clinical trials unit, Faculty of Medicine, University of Kelaniya, Ragama Sri Lanka. E-mail:vink1025@gmail.com 